\title{
Thermogravimetric and evolved gas analyses of high ash Indian and Turkish coal pyrolysis and gasification
}

\author{
Kandasamy Jayaraman ${ }^{1} \cdot$ Iskender Gokalp $^{1}$
}

Received: 9 July 2014/ Accepted: 27 January 2015/Published online: 26 June 2015

(c) The Author(s) 2015. This article is published with open access at Springerlink.com

\begin{abstract}
High ash coals from India and Turkey are investigated in this study. A coupled thermogravimetric analyzer and mass spectrometer system is used for the thermal decomposition characterization of the coal samples and the identification of the volatiles evolved during the various reaction regions. Coal samples are heated in argon, air, oxygen, steam and blended gas mixtures at the temperature range from 25 to $1250{ }^{\circ} \mathrm{C}$. The experiments are performed to study the pyrolysis, combustion and gasification characteristics of typical Indian and Turkish high ash coals. Thermogravimetry and derivative thermogravimetry studies are applied to measure the conversion level and half-life time of the coals/chars during and after pyrolysis. The maximum mass loss occurs during the devolatilization stage of coals at the temperatures from 350 to $700{ }^{\circ} \mathrm{C}$, where $\mathrm{O}_{2}, \mathrm{CO}_{2}, \mathrm{CO}, \mathrm{H}_{2}$ and a small amount of $\mathrm{CH}_{4}$ are released. Coal particles start to react with steam and produce $\mathrm{CO}_{2}, \mathrm{CO}$ and $\mathrm{H}_{2}$ when the temperature is increased above $750{ }^{\circ} \mathrm{C}$. The gasification reactions are completed around $950{ }^{\circ} \mathrm{C}$ in steam and steam blended ambience. The reactivity of high ash coal chars mainly depends on reagents' and surrounding gases concentration and also the reaction temperature. The results indicate that the size effect of the char particles is minimal at high gasification temperatures. Char gasification rates determined by TG techniques under isothermal conditions in different reagent flow rates and size effect contribute to enhance the knowledge on high ash coal thermal characterization and gasification and, therefore, to establish the
\end{abstract}

Kandasamy Jayaraman

jayaraman_mit@yahoo.com

1 ICARE-CNRS, 45071 Orléans, France optimum operational conditions for syngas production from high ash coals.

Keywords High ash coal · Pyrolysis - Combustion . Gasification · Gas analysis

\section{Introduction}

Coal gasification is considered as an effective approach toward the clean use of coal, especially for electricity production [1]. In addition, coal gasification also plays an increasingly important role in the production of liquid fuels and chemicals [2]. Coal is the fastest growing energy resource in the world with 826 billion tons of proven reserves [3] and also is expected to last for up to 200 years compared to about 65 and 40 years for natural gas and crude oil, respectively [4]. However, the increase in coal utilization results in growing environmental concerns due to greenhouse gas (GHG) emissions. Carbon dioxide is the major greenhouse gas, and its emissions from coal-fired power plants are very high, accounting for $40 \%$ of total global emissions [5]. The greenhouse gas emissions from fossil fuel-fired power generation can be reduced by achieving efficiency improvements, switching to lower carbon fuels and $\mathrm{CO}_{2}$ capture and storage (CCS) [6].

Due to the heterogeneous nature of coal and the large variety of coal conversion technologies available, it is essential to estimate coal reactivity under specified reaction conditions. Pyrolysis, gasification and combustion characteristics of a fuel used in energy production can be determined using thermo-analytical techniques such as thermogravimetry (TG), derivative thermogravimetry (DTG), differential thermal analysis (DTA), differential scanning calorimetry (DSC) and thermomechanical 
analysis (TMA). Thermogravimetric analysis is a method to evaluate the reactivity of materials and can be operated under isothermal and non-isothermal conditions. This technique is also employed in coal research particularly to determine the rate of mass loss either in an oxidant or in an inert atmosphere under dynamic heating conditions [7-10]. Saikia et al. [11] investigated the thermal characterization of two coal samples from India using XRD, FT-IR and TG analyses. They observed that dehydration occurs at lowtemperature region from 80 to $110^{\circ} \mathrm{C}$ and the maximum loss of volatile materials occurs due to primary and secondary volatilizations mainly in the $300-570{ }^{\circ} \mathrm{C}$ region. TG technique has also been coupled with other analytical techniques to provide information on the chemical features of the processes [12, 13].

Kök [14] reported differential scanning calorimetry and thermogravimetry (TG/DTG) analyses for the pyrolysis and combustion of 17 Turkish coal samples. Reaction intervals, peak and burnout temperatures of the coal samples were determined. Kök [15] also investigated the heating rate effect on coal combustion. Varol et al. [16] investigated the combustion and co-combustion characteristics of three biomass fuels and three Turkish lignite coals using a thermogravimetric analyzer. They observed that the increase in volatile matter content of the coal decreases the ignition temperature and increases the reactivity and that the maximum combustion rate is shifted to lower temperatures. Also, the maximum mass loss occurs at lower temperatures for more reactive coals. The use of non-isothermal pyrolysis with associated evolved gas analysis provides a qualitative explanation of the pyrolysis behavior of coal [17]. Pyrolysis is an important intermediate stage of all major coal conversion processes, such as combustion, gasification, carbonization and liquefaction. It is also a simple and effective method to remove sulfur from coal [18-22].

Arenillas et al. [23] performed the optimization of TGMS coupling and developed a normalization procedure allowing a semiquantitative comparison between pyrolysis gases from various rank coals. Nali et al. [12] performed gas chromatography and mass spectrometry studies for the pyrolysis of various Polish and US lignites. Seo et al. [24] studied coal pyrolysis using thermo-gravimetric analysis (TG) and concentration measurements of the evolved species for Chinese coals under non-isothermal conditions at various heating rates. Hou et al. [25] reported the gasification reactivity of the Hailar lignite and the catalytic effects of the present ash using thermogravimetric analysis under $\mathrm{N}_{2} / \mathrm{CO}_{2}$ ambience. Fan et al. [26] studied the gasification reactivity of coal chars with steam and $\mathrm{CO}_{2}$ at medium temperature ranges using thermogravimetric analysis. Everson et al. [27] investigated high inertinite coals using equilibrium concentrations of reagents during mixed gas experiments. Guizani et al. [28] investigated biomass gasification at similar conditions and also varied the reagent concentrations from 10 to $30 \%$. Several researchers [27-31] reported the temperature dependence of gasification reactivity. Kajitani et al. [32] reported the gasification rate of coal chars with different particle size distributions in a high-temperature zone. Jayaraman and Gökalp [33-35] investigated the size effects of Indian and Turkish coal and char particles during pyrolysis and gasification using coupled thermogravimetric and mass spectrum analysis.

High ash coals have been widely used for power and industrial steam generation in India and Turkey. Such coals are likely to remain a key energy source for these countries for several decades as they possess significant amounts of this domestic energy resource and also a large installed capacity for coal-based electricity production. With gasification, power generation efficiencies can be improved from $35 \%$ for coal combustion to between 45 and $55 \%$ [36]. The emissions of $\mathrm{CO}_{2}$ into the atmosphere can also be reduced or more easily captured. Furthermore, Campoy et al. [37] demonstrated that the appropriate combination of temperature and steam leads to higher $\mathrm{CO}$ and $\mathrm{H}_{2}$ yields, heating value, carbon conversion and gasification efficiency. The gasification optimization of high ash coals needs systematic identification and analysis of the formation and evolution of $\mathrm{H}_{2}$, $\mathrm{CO}$ and $\mathrm{CO}_{2}$ during the conversion processes. Also, it is necessary to understand the pyrolysis mechanisms in order to increase the conversion rate of coal into gases, especially to increase the $\mathrm{H}_{2}$ content. This paper investigates the thermochemical reactions during the pyrolysis of coal and during coal and char combustion and gasification processes as a continuation of the work presented in [33-35].

\section{Experimental}

A NETZSCH STA 429 thermal analyzer combined with a quadrupole QMG 511 mass spectrometer and steam generator is used in this study to perform investigations on coal conversion in various atmospheres with the flow rates of $6 \mathrm{~g} \mathrm{~h}^{-1}$ of steam, $2 \mathrm{~mL} \mathrm{~min}^{-1}$ of air, $2 \mathrm{~mL} \mathrm{~min}^{-1}$ for the gasification process and for the combustion process with $50 \mathrm{~mL} \mathrm{~min}^{-1}$ of oxygen and $20 \mathrm{~mL} \mathrm{~min}^{-1}$ of argon. The experimental details are presented in detail elsewhere [33, 38, 39]. During the experiments, about $15 \mathrm{mg}$ of coal sample is placed in a ceramic crucible and heated up to $1150{ }^{\circ} \mathrm{C}$ with the heating rate of $35^{\circ} \mathrm{C} \mathrm{min}{ }^{-1}$. In some experiments, isothermal conditions are maintained from 850 to $1000{ }^{\circ} \mathrm{C}$ with steps of $50{ }^{\circ} \mathrm{C}$. Turkish coal is from the Tunçbilek region, whereas the Indian coal is from Bilaspur. Three particle sizes are used in isothermal gasification experiments, namely 60, $800 \mu \mathrm{m}$ and $3 \mathrm{~mm}$. Mass spectrometric analysis is used to detect the gas evolution during the thermochemical reactions. The excitation 
Table 1 Proximate analysis, ultimate analysis and heating values of the coal samples

\begin{tabular}{|c|c|c|}
\hline & Turkish coal & Indian coal \\
\hline \multicolumn{3}{|c|}{ Proximate analysis $/ \%$} \\
\hline Moisture & 11.15 & 2.95 \\
\hline Ash & 49.23 & 45.85 \\
\hline V.M & 24.60 & 25.62 \\
\hline Fixed carbon & 15.02 & 25.58 \\
\hline Total & 100 & 100 \\
\hline \multicolumn{3}{|c|}{ Ultimate analysis/\% } \\
\hline $\mathrm{C}$ & 32.6 & 39.43 \\
\hline $\mathrm{H}$ & 2.23 & 2.52 \\
\hline $\mathrm{N}$ & 0.99 & 0.97 \\
\hline $\mathrm{O}$ & 7.16 & 10.78 \\
\hline$S$ & - & 0.45 \\
\hline \multicolumn{3}{|c|}{ Heating value/MJ $\mathrm{kg}^{-1}$} \\
\hline LCV & 10 & 14.6 \\
\hline $\mathrm{HCV}$ & 10.8 & 15.2 \\
\hline
\end{tabular}

energy in the mass spectrometer is $1100 \mathrm{eV}$. The TG-MS experiments were carried out in a dynamic gas atmosphere. The output of the TG system is connected to the mass spectrometer through a heated line. The balance adapter, the transfer line and the MS gas cell are maintained at $250{ }^{\circ} \mathrm{C}$, thus avoiding the condensation of the less volatile compounds. Steam generator and steam transfer line are maintained at 180 and $150{ }^{\circ} \mathrm{C}$, respectively. The low volumes in the thermobalance microfurnace, transfer line and the gas measurement cell permit low carrier gas flow rates to be used and allow good detection of the gases evolved during the pyrolysis, combustion and gasification processes. The accuracy of TG experiments is within acceptable limits. Online gas analyses were performed for the detection of the gases fed to mass spectrometer, and experimental data are stored as a function of time. The ultimate and proximate analyses of the Indian and Turkish coal are given in Table 1.

TG experimental results obtained as mass loss versus time data are converted to conversion degree $(\mathrm{X})$ versus time profiles (on ash-free basis) as

$X=\frac{m_{0}-m}{m_{0}-m_{\mathrm{ash}}}$

where $m$ is the mass of the sample at time $t, m_{0}$ is the initial mass, and $m_{\text {ash }}$ is the remaining mass corresponding to the ash content of the sample. The apparent reaction rate is calculated as a differential of the conversion degree versus time, denoted as $\frac{\mathrm{d} X}{\mathrm{~d} t}$. The half-life time $t_{0.5}$ indicating the time needed for $50 \%$ conversion of carbon in chars [24] is used as a reactivity index in this work to characterize the gasification reactivity of coal chars for quantitative comparisons.

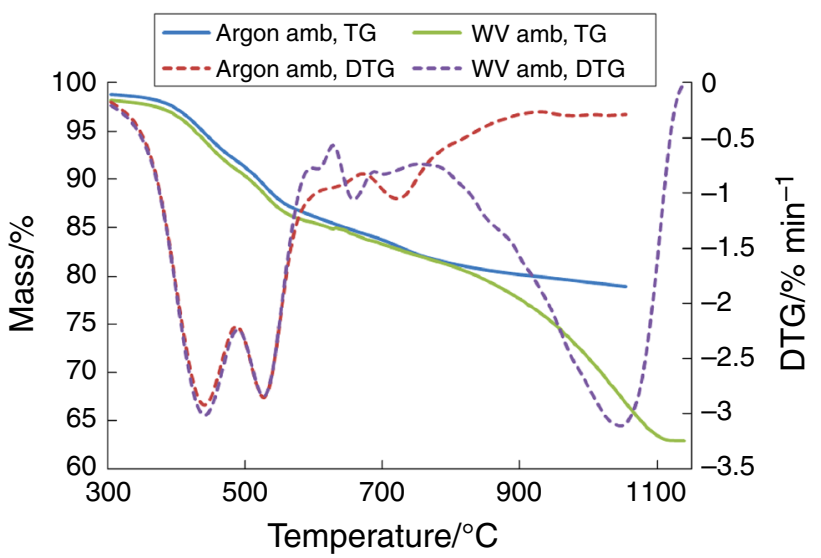

Fig. 1 TG curves of Turkish coal

\section{Results and discussion}

\section{Thermal decomposition}

The experiments are carried out in argon and steam ambiences to evaluate the thermal decomposition of the coal. The TG-DTG curves of the Turkish and Indian coals indicate that pyrolysis of coals mainly occurs in the temperature range from 300 to $750{ }^{\circ} \mathrm{C}$, presented in Figs. 1, 4 and Table 2. The evolution of gaseous species as a result of decomposition of the coal sample is simultaneously monitored by mass spectrometry during thermogravimetric experiments. The mass spectra of the gases evolved during pyrolysis and gasification are illustrated in Figs. 2 and 3 for the Turkish coal, respectively. Figure $5 \mathrm{a}$, b shows the mass spectra of the evolved gases in argon and water vapor ambiences, respectively, for the Indian coal. The spectra are detected for increasing temperatures so at increasing times. As can be seen from Figs. 1 and 3, some mass loss is noticed for Turkish coal for temperatures below $300{ }^{\circ} \mathrm{C}$ due to the elimination of the moisture which is higher for the Turkish coal (see Table 1).

As presented in the Figs. 1 and 4, steam decomposition and coal gasification commence from $800{ }^{\circ} \mathrm{C}$. The pyrolysis characteristics of the coals are the same when the coal is heated until $800{ }^{\circ} \mathrm{C}$ either in argon or in steam ambience, which was also reported by Hou et al. [25]. At temperatures below $350-400{ }^{\circ} \mathrm{C}$, different processes take place prior to primary pyrolysis, i.e., disruption of hydrogen bonds, vaporization and transport of the non-covalently bonded molecular phase [40]. The second peak, where the essential mass loss occurs in the range of $350-700{ }^{\circ} \mathrm{C}$, is related to primary devolatilization, during which carbon, hydrogen and oxygen containing species are released (Figs. 2, 4). At $350{ }^{\circ} \mathrm{C}$, the primary carbonization starts with the release of carbon dioxide and hydrogen. Subsequently, with increasing temperature, methane and other lower aliphatics are 
Table 2 Pyrolysis and steam gasification parameters of Indian and Turkish coal

\begin{tabular}{llllll}
\hline Process & Origin of coal & Ambient conditions & Temperature range $/{ }^{\circ} \mathrm{C}$ & Peak temperature $/{ }^{\circ} \mathrm{C}$ & Total mass loss $/ \%$ \\
\hline Pyrolysis & India & Argon & $315-900$ & 440 & 22 \\
Pyrolysis & Turkey & Argon & $300-910$ & 480 & 19.6 \\
Gasification & India & Steam & $780-1100$ & 940 & 25.1 \\
Gasification & Turkey & Steam & $752-1102$ & 1035 & 18.2 \\
\hline
\end{tabular}

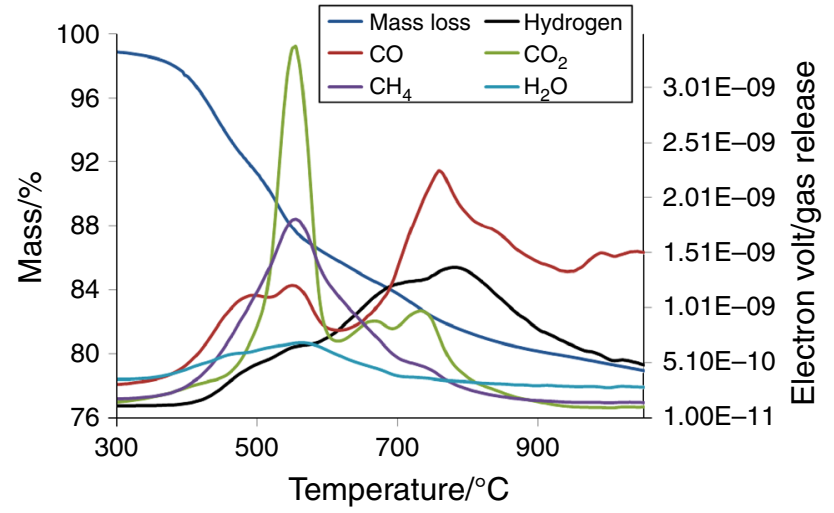

Fig. 2 Mass spectrum analysis (gas detection) of Turkish coal in argon

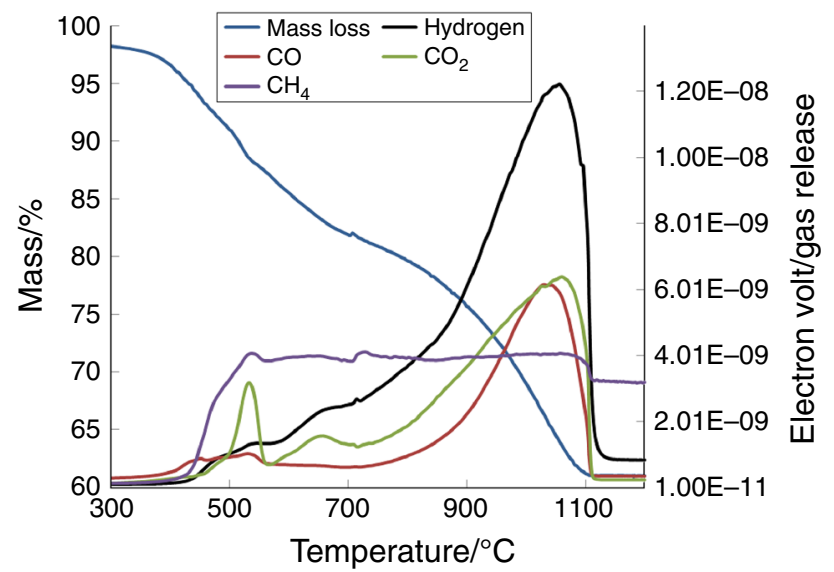

Fig. 3 Mass spectrum analysis (gas detection) of Turkish coal in steam

evolved together with hydrogen, carbon monoxide and alkyl aromatics [11]. When comparing the DTG curves of Turkish and Indian coal decomposition, the rate of devolatilization is observed to decrease (Figs. 1, 4) for the Turkish coal with higher ash and moisture content. This rapid devolatilization process is essentially completed at $550{ }^{\circ} \mathrm{C}$. Secondary devolatilization of coal, occurring in the $600-900{ }^{\circ} \mathrm{C}$ ranges, produces $\mathrm{CO}, \mathrm{CO}_{2}, \mathrm{H}_{2} \mathrm{O}, \mathrm{H}_{2}$ and $\mathrm{CH}_{4}$ as the major products. The maxima in the DTG curves correspond to the maximum gas release (Figs. 1, 2, 3, 4). $\mathrm{H}_{2}$ peaks are detected during thermal decomposition at the temperature range of $500-750{ }^{\circ} \mathrm{C}$. It can be seen in Figs. 2 and $5 \mathrm{a}$ that the formation of $\mathrm{CH}_{4}$ starts at temperatures higher than $450{ }^{\circ} \mathrm{C}$. Also, it can be noted that higher volatile matter content coals produce more $\mathrm{CH}_{4}$ during pyrolysis processes. In the case of high ash coals, $\mathrm{CO}_{2}$ is formed from aliphatic and aromatic carboxyl and carboxylate groups at low temperatures.

\section{Combustion tests}

Combustion tests of the high ash coals are carried out in oxygen-enriched $\left(75 \% \mathrm{O}_{2}\right.$ and $25 \%$ argon) ambient conditions. Figure 6 shows the temporal mass losses and DTG curves for Turkish and Indian coals under those conditions. The characteristic temperatures and parameters such as $T_{\mathrm{ig}}$ (ignition temperature), $T_{\mathrm{pmax}}$ (the temperature corresponding to the peak of the derivative thermogravimetric-DTG curve), $T_{\mathrm{b}}$ (burn out temperature) and I(d $m /$ $\mathrm{d} t)_{2 \max } \mathrm{l}$ are investigated to explore the ignition and combustion behavior of the coal samples. In the case of Turkish coal, a small amount of mass loss is observed at $120{ }^{\circ} \mathrm{C}$ due to its moisture content.

Coal reactivity is primarily assessed based on the peak temperature $T_{\mathrm{pmax}}$ [41]. Higher values of this temperature indicate less reactive coals, meaning that coals with larger mass loss rates observed at lower temperatures are easier to ignite and burn. TG profiles extending into high-temperature ranges indicate slow burning coals, for which longer combustion times are required for complete combustion. The burn out temperature of the Turkish coal is around $675{ }^{\circ} \mathrm{C}$ and around $875{ }^{\circ} \mathrm{C}$ for the Indian coal. For both coals, the mass loss starts above $320^{\circ} \mathrm{C}$, and the combustion process starts around $400{ }^{\circ} \mathrm{C}$ which is slightly higher than the reported values of Wang et al. [41] for high ash coals. Devolatilization is followed by the fixed carbon combustion which takes place in a continuous manner with a single peak for Turkish coal, whereas the Indian coal demonstrates longer duration for combustion and shows some plateau region in the final stage.

\section{Coal gasification}

The gasification process is exceedingly complex, and many competing processes contribute to its features. In this 


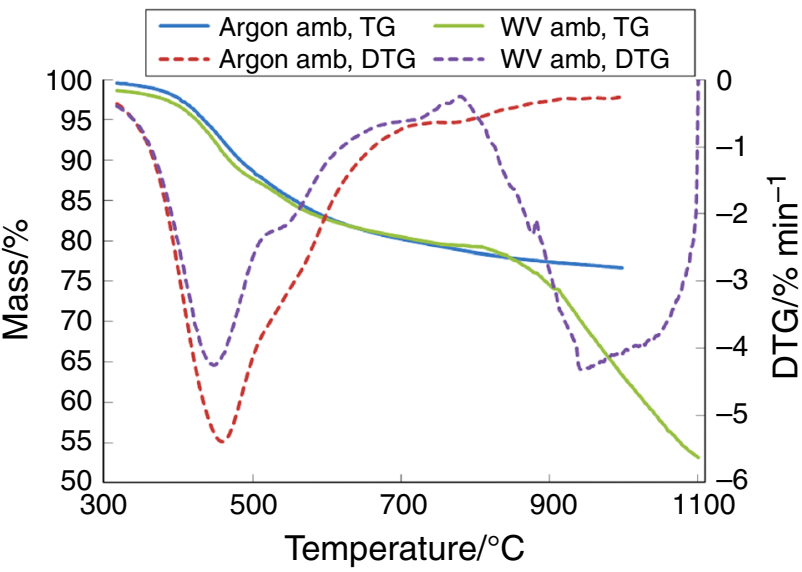

Fig. 4 TG curves of Indian of coal
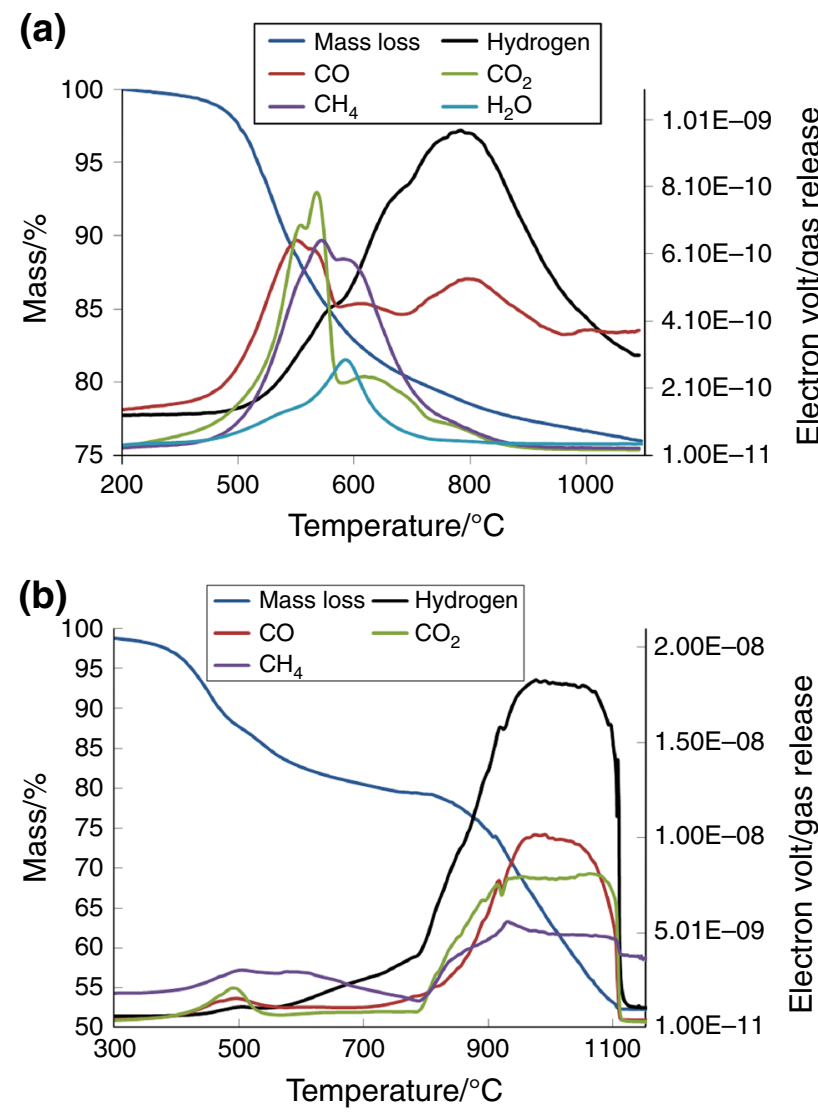

Fig. 5 Mass spectrum analysis (gas detection) of Indian coal. a Argon, b steam

study, the coal sample is subjected to a dynamic heating rate of $40{ }^{\circ} \mathrm{C} \mathrm{min}{ }^{-1}$ until $1150{ }^{\circ} \mathrm{C}$ in the presence of steam and in steam blended air/oxygen ambience (Fig. 7). The mass loss versus time curves show two sequential zones as the coal is exposed to the heating environment. The first zone of mass loss for temperatures below $700{ }^{\circ} \mathrm{C}$ and

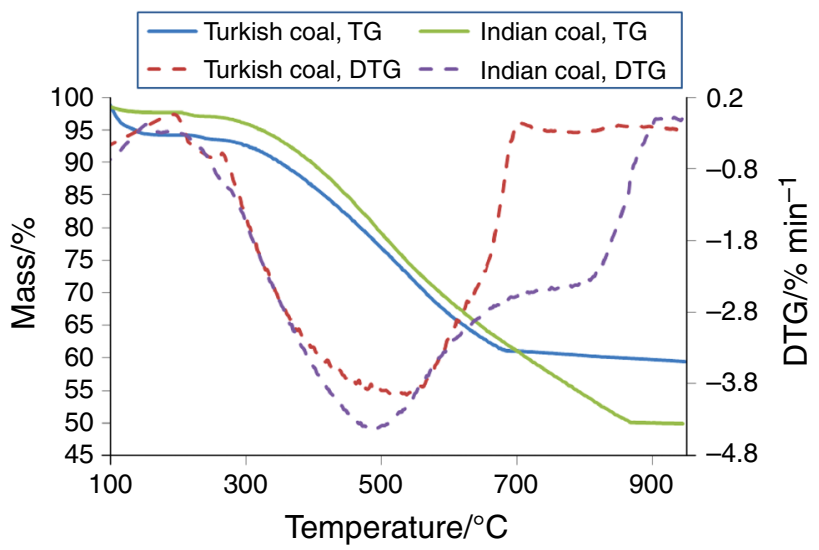

Fig. 6 TG curves in oxygen

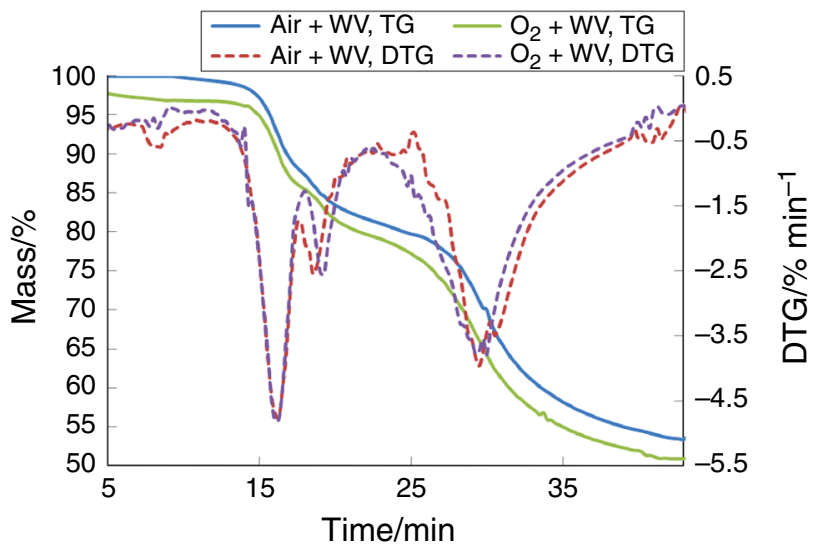

Fig. 7 TG curves of non-isothermal conditions in blended gases of Indian coal

conversion up to $20 \%$ is the pyrolysis stage, whose characteristics are not affected by the presence of argon or steam environment. The residual mass of the samples in water vapor ambience infers that the complete gasification of the coal samples occurs at $950{ }^{\circ} \mathrm{C}$ as observed when Figs. 6 and 9 are compared. Table 2 compares the temperature regions of pyrolysis and steam gasification for both coals.

Maxima in the intensities of the gas evolution are always accompanied by maxima in the mass loss as observed when Figs. 7-9 are compared. The major gases evolved from coal gasification are $\mathrm{CO}, \mathrm{H}_{2}, \mathrm{CH}_{4}$ and $\mathrm{CO}_{2}$ as shown in Fig. 8a, b.

\section{Effect of reagent flow rates during isothermal gasification}

The reagent flow rate has a marked influence on the gasification reactivity of the fuel char. The gasification 


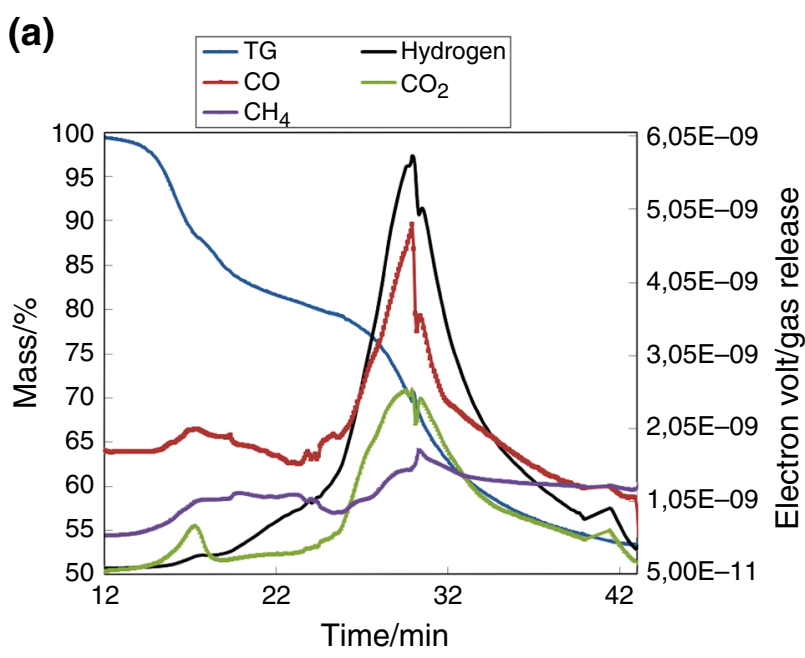

(b)

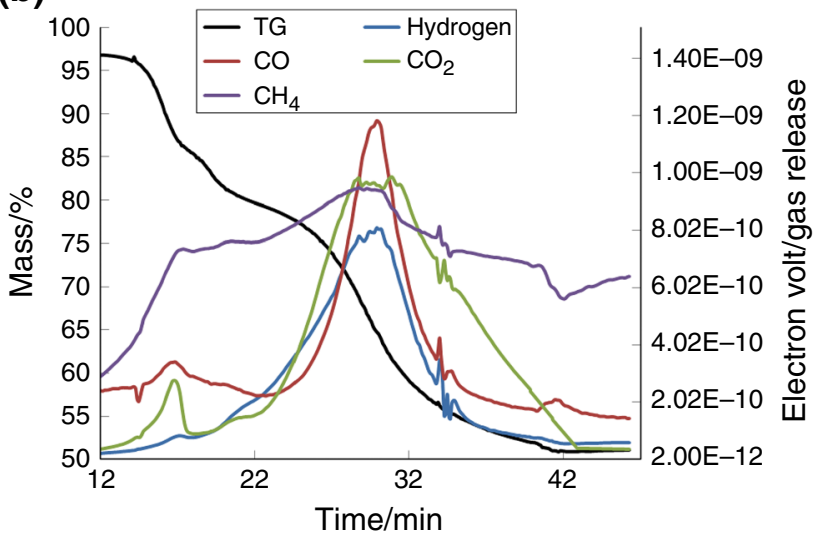

Fig. 8 Mass spectrum analysis (gas detection) of coal samples in air and steam blended ambience. a Turkish coal, b Indian coal

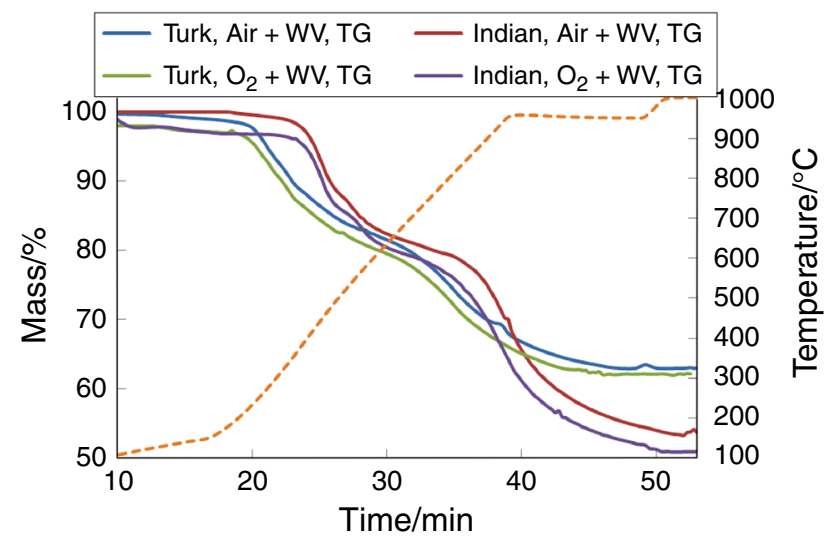

Fig. 9 Comparison of TG curves in blended gases of Turkish and Indian coal

experiments are performed under isothermal conditions at 850,900 and $950{ }^{\circ} \mathrm{C}$. The gasification rate of $3 \mathrm{~mm}$ Turkish coal particles under isothermal conditions is

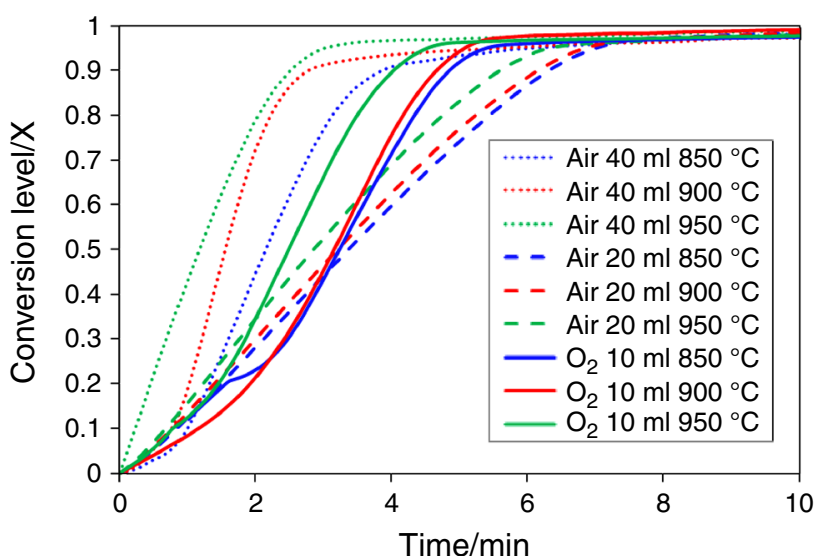

Fig. 10 Effect of partial pressure and temperature on isothermal gasification of Turkish coal with the size of $3 \mathrm{~mm}$

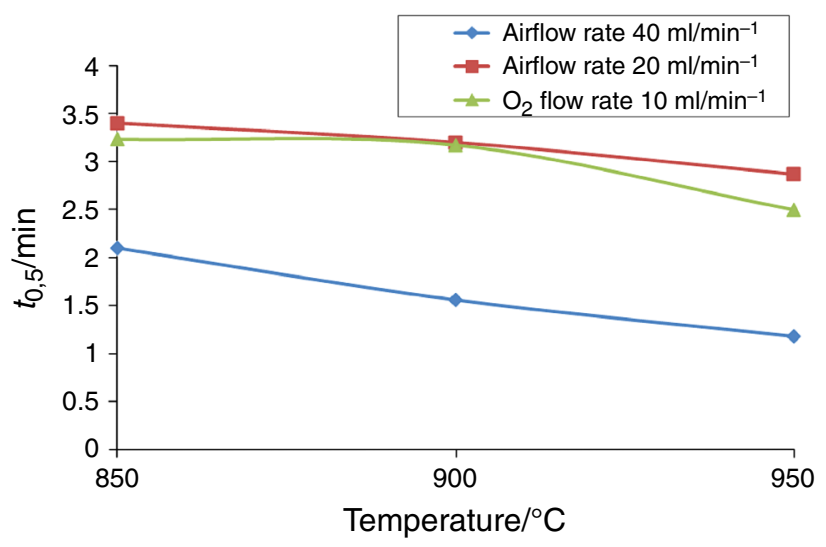

Fig. 11 Effect of gasification temperature on $t_{0.5}$ for various reagent flow rates

examined as illustrated in Fig. 10. In these experiments, the coal particles are pyrolyzed in argon atmosphere with the flow rate of $40 \mathrm{~mL} \mathrm{~min}{ }^{-1}$. After reaching the prescribed temperature, the isothermal gasification reaction of the char samples is initiated by switching on to the air/ $\mathrm{O}_{2}$ stream with the required flow rate. The char sample is then allowed to react until the stabilization of mass loss. For the air flow rates of 40 and $20 \mathrm{~mL} \mathrm{~min}^{-1}$, the corresponding partial pressures of oxygen are 0.12 and 0.08 , whereas in the oxygen flow rate of $10 \mathrm{~mL} \mathrm{~min}^{-1}$, the partial pressure of oxygen is 0.2 . Figure 10 shows that increasing the gasification reagent flow rate increases the conversion level and the conversion level is higher with $40 \mathrm{~mL} \mathrm{~min}-1$ of air when compared to the $\mathrm{O}_{2}$ flow rate of $10 \mathrm{~mL} \mathrm{~min}{ }^{-1}$, with higher oxygen partial pressure in this last case. Figure 11 shows that the half-life of gasification decreases as the gasification temperature increases and that the flow rate of the gasification reagent has a dominant effect. 


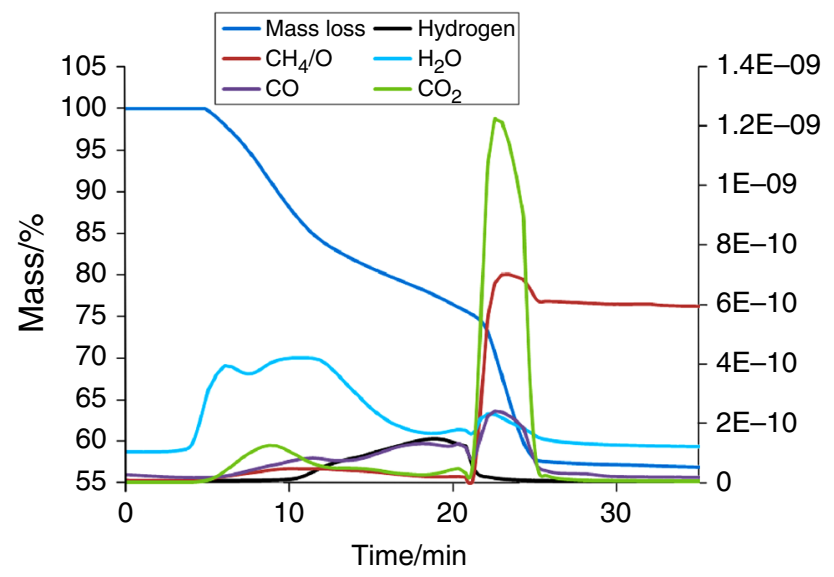

Fig. 12 Mass spectrum analysis (gas detection) of $3 \mathrm{~mm}$ Turkish coal in argon $\left(40 \mathrm{ml} \mathrm{min} \mathrm{min}^{-1}\right)$ and $\mathrm{O}_{2}\left(10 \mathrm{ml} \mathrm{min}^{-1}\right)$ ambience at $850{ }^{\circ} \mathrm{C}$

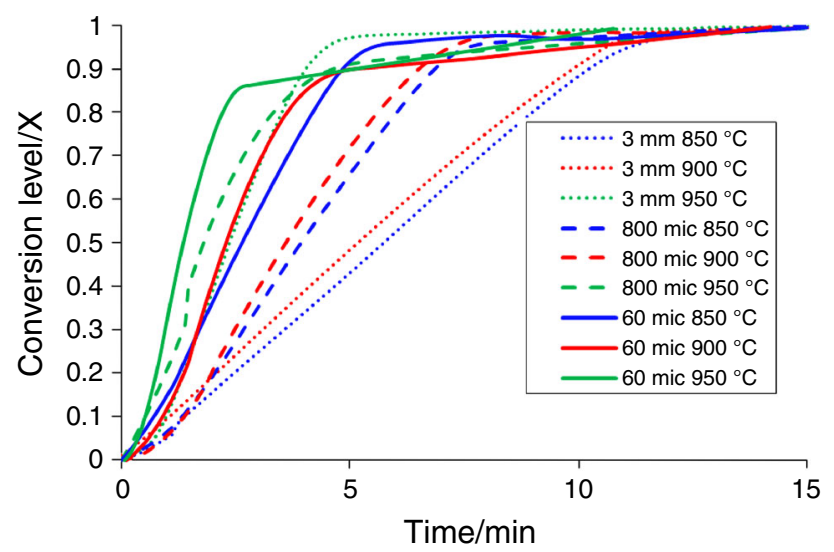

Fig. 13 Effect of particle size and temperature on isothermal gasification of Turkish coal in air and steam gasification

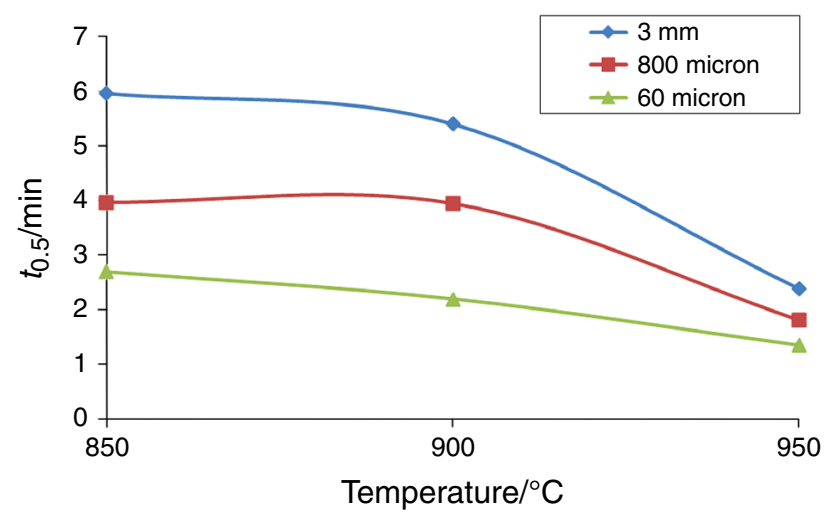

Fig. 14 Effect of gasification temperature on $\mathrm{t}_{0.5}$ for different-sized particles

It can be concluded that the reactivity of high ash coal chars mainly depends on reagents' and surrounding gases concentrations and also the reaction temperature. Similar results have also been observed by other researchers
[28, 29, 31, 32]. Figure 12 shows the formation of evolved gases for the oxygen concentration of $20 \%$ under isothermal conditions.

\section{Effect of particle sizes during isothermal gasification}

The effect of particle size on char conversion level is shown in Fig. 13. In the initial stage of gasification, the conversion rates are almost identical, but as time proceeds, gasification rate differences are observed for different particle sizes. It can be seen that $60 \mu \mathrm{m}$ particles reach about $80 \%$ conversion level within $10 \mathrm{~min}$, whereas $800 \mu \mathrm{m}$ particles take $7 \mathrm{~min}$ and $3 \mathrm{~mm}$ particles more than $10 \mathrm{~min}$ to reach the same conversion level. Since smaller particles exhibit higher gasification rates, the diffusion restrictions and heat transfer limitations cannot be neglected for this type of high ash coal. As also mentioned in [32], with decreasing char particle size, the TG curves shift to the lower temperature zone and gasification time is shortened. This is due to the fact that smaller coal particles have more specific area than the larger ones and facilitate the ignition and reaction of char particles. Figure 14 shows that the half-life time of conversion of small char particles decreases consistently as gasification temperature increases. On the other hand, the $800 \mu \mathrm{m}$ and $3 \mathrm{~mm}$ particles gasification rate is quite significantly high for the gasification temperature of $900{ }^{\circ} \mathrm{C}$. These results indicate that the size effect of the char particles is lower at higher gasification temperatures for the experimental conditions explored here.

\section{Conclusions}

The pyrolysis, combustion and gasification behaviors of high ash Turkish and Indian coals are investigated by the coupled TG-MS method. The results indicate that the ignition temperature and the temperature of maximum mass loss rate are identical for both coals, but the burn out temperature of Indian coal is higher. During thermal decomposition and devolatilization of the coal, $\mathrm{CO}, \mathrm{CO}_{2}$, $\mathrm{H}_{2}$ and $\mathrm{CH}_{4}$ are the major gaseous products. The gasification process of the coal starts around $700{ }^{\circ} \mathrm{C}$ for blended mixtures of steam, air and oxygen. The complete burn out of both coal samples occurs at $950{ }^{\circ} \mathrm{C}$ which indicates the optimum gasification temperature for higher carbon conversion rate and cold gas efficiency for high ash coals.

The conversion half-life time of the chars decreases as the gasification temperature increases and the effect of gasification temperature on $t_{0.5}$ is quite significant above the gasification temperature of $900{ }^{\circ} \mathrm{C}$ under high oxygen flow rates. It can be concluded that the reactivity of high ash coal chars mainly depends on reagents' and 
surrounding gases concentration and the reaction temperature. These results also indicate that the size effect of char particles is minimal at higher gasification temperatures, for the temperature and coal/char sizes tested. Hence, the results of the paper indicate that the combined effects of char size and gasification temperature control the gasification reactivity of high ash coals.

Acknowledgements Financial support for this work is provided by the European Commission under Project OPTIMASH FP7-ENERGY, 2011-1 Project No 283050.

Open Access This article is distributed under the terms of the Creative Commons Attribution License which permits any use, distribution, and reproduction in any medium, provided the original author(s) and the source are credited.

\section{References}

1. International energy agency. Key world energy statistics IEA. (2010). www.iea.org/stats/index.asp.

2. Couch G. Coal to liquids. IEA Clean Coal Centre: 2008.

3. BP Statistical review of world energy (2010). http://www.bp. com.

4. World coal institute, coal: liquid fuels (2006). http://www.world coal.org/resources/wca-publications/.

5. Deutch J, Moniz J. The future of coal: options for a carbonconstrained world. Massachusetts Institute of Technology Interdisciplinary Study. 2007.

6. Wall T, Liu Y, Spero C, Elliott L, Khare S, Rathnam R. An overview on oxyfuel coal combustion-state of the art research and technology development. Chem Eng Res Des. 2009;87:1016103.

7. Avid B, Purevsuren B, Born M, Dugarjav J, Davaajav Y, Tuvshinjargal A. Pyrolysis and TG analysis of shivee ovoo coal from mongolia. J Therm Anal Calorim. 2002;68:877-85.

8. Diaz-Faes E, Barriocanal C, Diez MA, Alvarez R. Applying TGA parameters in coke quality prediction models. J Anal Appl Pyrolysis. 2007;79:154-60.

9. Arenillas A, Rubiera F, Arias B, Pis JJ, Faundez JM, Gordon AL, Garcia XA. A TG/DTA study on the effect of coal blending on ignition behavior. J Therm Anal Calorim. 2004;76: 603-14.

10. Fangxian L, Shizong L, Youzhi C. Thermal analysis study of the effect of coal-burning additives on the combustion of coals. J Therm Anal Calorim. 2009;95:633-8.

11. Saikia BK, Boruah RK, Gogoi PK, Baruah BP. A thermal investigation on coals from Assam (India). Fuel Proc Technol. 2009;90:196-203.

12. Nali M, Corana F, Montanari L, Pellegrini LA. Pyrolysis-gas chromatography/mass spectrometry study on coals. J Anal Appl Pyrolysis. 1994;29:15-23.

13. Groenewoud WM, De Jong W. The thermogravimetric analyser-coupled-Fourier transform infrared/mass spectrometry technique. Thermochim Acta. 1996;286:341-54.

14. Kök MV. Temperature-controlled combustion and kinetics of different rank coal samples. J Therm Anal Calorim. 2005;79:175-80.

15. Kök MV. Simultaneous thermogravimetry-calorimetry study on the combustion of coal samples: effect of heating rate. Energy Convers Manag. 2012;53:40-4.
16. Varol M, Atimtay AT, Bay B, Olgun H. Investigation of cocombustion characteristics of low quality lignite coals and biomass with thermogravimetric analysis. Thermochim Acta. 2010;510:195-201.

17. Van Heek KH, Hodek W. Structure and pyrolysis behaviour of different coals and relevant model substances. Fuel. 1994;73:886-96.

18. Hu H, Zhou Q, Zhu S, Meyer B, Krzack S, Chen G. Product distribution and sulfur behavior in coal pyrolysis. Fuel Process Technol. 2004;85:849-61.

19. Gryglewicz G. Effectiveness of high temperature pyrolysis in sulfur removal from coal. Fuel Process Technol. 1996;46:217-26.

20. Zhou Q, Hu H, Liu Q, Zhu S, Zhao R. Effect of atmosphere on evolution of sulfur containing gases during coal pyrolysis. Energy Fuels. 2005;19:892-7.

21. Karaca S. Desulfurization of a Turkish lignite at various gas atmospheres by pyrolysis: effect of mineral matter. Fuel. 2003;82:1509-16.

22. Czaplicki A, Smolka W. Sulfur distribution within coal pyrolysis products. Fuel Process Technol. 1998;55:1-11.

23. Arenillas A, Rubiera F, Pis JJ. Simultaneous thermogravimetricmass spectrometric study on the pyrolysis behaviour of different rank coals. J Anal Appl Pyrolysis. 1999;50:31-46.

24. Seo DK, Parka SS, Kim YT, Hwang J, Yu Tae-U. Study of coal pyrolysis by thermo-gravimetric analysis (TGA) and concentration measurements of the evolved species. J Anal Appl Pyrolysis. 2011;92:209-16.

25. Hou A, Wang Z, Song W, Lin W. Thermogravimetric analysis on gasification reactivity of Hailar lignite. J Therm Anal Calorim. 2012;109:337-43.

26. Fan D, Zhu Z, Na Y, Lu Q. Thermogravimetric analysis of gasification reactivity of coal chars with steam and $\mathrm{CO}_{2}$ at moderate temperatures. J Therm Anal Calorim. 2013;113:599-607.

27. Everson R, Neomagus H, Kasani H, Njapha D. Reaction kinetics of pulverised coal-chars derived from inertinite-rich coal discards: characterisation and combustion. Fuel. 2006;85:1067-75.

28. Guizani C, Escudero Sanz F, Salvador S. The gasification reactivity of high-heating-rate chars in single and mixed atmospheres of $\mathrm{H}_{2} \mathrm{O}$ and $\mathrm{CO}_{2}$. Fuel. 2013;108:812-23.

29. Ye D, Agnew J, Zhang D. Gasification of a South Australian lowrank coal with carbon dioxide and steam: kinetics and reactivity studies. Fuel. 1997;77:1209-19.

30. Xu Q, Pang S, Levi T. Reaction kinetics and producer gas composition of steam gasification of coal and biomass blend chars, part 1: experimental investigation. Chem Eng Sci. 2011;66:2141-8.

31. Irfan MF, Usman MR, Kusakabe K. Coal gasification in $\mathrm{CO}_{2}$ atmosphere and its kinetics since 1948: a brief review. Energy. 2011;36:12-40.

32. Kajitani S, Suzuki N, Ashizawa M, Hara S. $\mathrm{CO}_{2}$ gasification rate analysis of coal char in entrained flow coal gasifier. Fuel. 2006;85:163-9.

33. Jayaraman K, Gökalp I. Thermal characterization, gasification and kinetic studies of different sized Indian coal and char particles. Int J Adv Eng Sci Appl Math. 2014;6:31-40.

34. Jayaraman K, Gökalp I. Effect of char generation method on steam, $\mathrm{CO}_{2}$ and blended mixture gasification of high ash Turkish coals. Fuel. doi:10.1016/j.fuel.2015.01.065.

35. Jayaraman K, Gökalp I. Gasification characteristics of petcoke and coal blended petcoke using thermogravimetry and mass spectrometry analysis. Appl Thermal Eng. 2015;80:10-9.

36. Schimmoller BK. Coal gasification. Power Eng. 2005;30-40.

37. Campoy M, Gomez-Barea A, Vidali FB, Ollero P. Air-steam gasification of biomass in a fluidised bed: process optimisation by enriched air. Fuel Process Technol. 2009;90:677-85. 
38. Jayaraman K, Gokalp I. Pyrolysis, combustion and gasification characteristics of miscanthus and sewage sludge. Energy Convers Manag. 2014;89:83-91.

39. Jayaraman K, Gokalp I. Pyrolysis, combustion and steam gasification of various types of scrap tires for energy recovery. Energy Fuels. 2015;29:346-54.
40. Wilson. Method for increasing steam decomposition in a coal gasification process, US Patent No. 4,786,291, 1998.

41. Wang C. Yongbo Du, Che D. Reactivities of coals and synthetic model coal under oxy-fuel conditions. Thermochim Acta. 2013;553:8-15. 